\title{
Life-cycle assessment of a waste refinery process for enzymatic treatment of municipal solid waste
}

Tonini, Davide; Astrup, Thomas

Published in:

Waste Management

Link to article, DOI:

10.1016/j.wasman.2011.07.027

Publication date:

2012

Document Version

Peer reviewed version

Link back to DTU Orbit

Citation (APA):

Tonini, D., \& Astrup, T. (2012). Life-cycle assessment of a waste refinery process for enzymatic treatment of municipal solid waste. Waste Management, 32(1), 165-176. https://doi.org/10.1016/j.wasman.2011.07.027

\section{General rights}

Copyright and moral rights for the publications made accessible in the public portal are retained by the authors and/or other copyright owners and it is a condition of accessing publications that users recognise and abide by the legal requirements associated with these rights.

- Users may download and print one copy of any publication from the public portal for the purpose of private study or research.

- You may not further distribute the material or use it for any profit-making activity or commercial gain

- You may freely distribute the URL identifying the publication in the public portal

If you believe that this document breaches copyright please contact us providing details, and we will remove access to the work immediately and investigate your claim. 


\title{
Life-cycle assessment of a waste refinery process for enzymatic treatment of municipal solid waste
}

\author{
Davide Tonini* and Thomas Astrup \\ Department of Environmental Engineering, Technical University of Denmark, DTU - \\ Building 115, $2800 \mathrm{Kgs}$. Lyngby, Denmark \\ * Corresponding author: dait@env.dtu.dk \\ Telephone: +4545251699 \\ Fax: +45 45932850
}

\section{Accepted version of the article:}

Tonini, D., Astrup, T., 2012. Life-cycle assessment of a waste refinery process for enzymatic treatment of municipal solid waste. Waste Manage. 2012, 32, 165-76.

This version did not undergo proof-reading and final journal editing. When referring to this work, please cite the journal publication stated above. 


\begin{abstract}
Decrease of fossil fuel dependence and resource saving has become increasingly important in recent years. From this perspective, higher recycling rates for valuable materials (e.g. metals) as well as energy recovery from waste streams could play a significant role substituting for virgin material production and saving fossil resources. This is especially important with respect to residual waste (i.e. the remains after source-separation and separate collection) which in Denmark is typically incinerated. In this paper, a life-cycle assessment and energy balance of a pilot-scale waste refinery for the enzymatic treatment of municipal solid waste (MSW) is presented. The refinery produced a liquid (liquefied organic materials and paper) and a solid fraction (non-degradable materials) from the initial waste. A number of scenarios for the energy utilization of the two outputs were assessed. Co-combustion in existing power plants and utilization of the liquid fraction for biogas production were concluded to be the most favourable options with respect to their environmental impacts (particularly global warming) and energy performance. The optimization of the energy and environmental performance of the waste refinery was mainly associated with the opportunity to decrease energy and enzyme consumption.
\end{abstract}

\title{
1. Introduction
}

Recovery of material resources and energy from mixed municipal solid waste (MSW) has obtained an increased level of attention in the last decade. While recovery of recyclable materials from more well-defined waste types, such as: source segregated waste, co-mingled waste or specific industrial/commercial wastes, is possible and typically carried out with good results, material recovery from residual household waste left after source segregation is often difficult due to the material properties of the waste (wet, mixed materials). Residual household waste may alternatively be incinerated and in countries such as Denmark, Sweden, Germany, Austria, and The Netherlands this occurs with very high energy recovery rates. In Denmark, waste incineration contributes with about $5 \%$ of the national electricity production and $20 \%$ of the district heating (Astrup et al., 2009). While residual waste may be a significant contributor to energy production, recovery of material resources is often limited to the extraction of metals (magnetic and non-magnetic) from the ashes produced. Furthermore, waste incinerators must operate as stable as possible throughout the year with limited options for adjusting energy production to the demands of society (Fruergaard et al., 2010). In the future with an increasing shares of fluctuating energy sources in the energy system (e.g. wind power) and greater needs for recovery and recycling of materials due to resource scarcity, 
integrated technologies which both allow material recovery and flexible energy production from "difficult" waste types such as mixed MSW are considered to be essential.

Waste refineries are one example of a group of integrative technologies which could process mixed residual waste types and produce a range of valuable outputs, including both recyclable materials and fuels for flexible energy production. Only a few studies have yet provided an evaluation of waste refinery processes and these studies have mainly focused on agricultural waste: in Larsen et al. (2008), a large-scale plant for bioethanol production from lignocellulosic biomass was presented. In Lohrasby et al. (2010), a citrus waste biorefinery was described. Papatheofanous et al. (1995) detailed a pilot-plant biorefinery for agricultural residues. Most studies have focused on lab-scale experiments for the optimization of the biorefinery processes: in Kaparaju et al. (2009), the yields of different products from a rapeseed-based biorefinery were investigated in a lab-scale setup. Talebnia et al. (2007) presented an overview of pretreatment, hydrolysis and fermentation experiences for bioethanol production from wheat straw. Examples of outputs from waste refineries are solid and liquid fuels as well as recoverable materials, such as metals, plastic and nutrients. Waste refineries may be similar in concept to biorefineries (Jensen et al., 2010), which also produce a range of valuable outputs from a biomass input, and process similarities may exist between the two types of refineries.

In order to assess whether waste refineries are environmentally beneficial for treating residual waste compared with existing treatment options such as incineration with post sorting of metals, a holistic and systematic assessment of both direct and indirect environmental impacts is required. Life cycle assessment is a useful tool for this. Several LCA studies have focused on biorefineries for corn, agricultural waste and other lignocellulosic biomasses (e.g. straw and grass): in the most recent studies, Cherubini and Ulgiati (2009) evaluated the environmental impacts using life-cycle assessment (LCA) and other sustainability indicators for a biorefinery concept converting wheat straw and corn stover into ethanol, biogas and other marketable chemical products. Uihlein and Schebek (2009) evaluated the environmental burdens of a lignocellulose feedstock biorefinery compared to fossil fuels systems. Cherubini and Stroemman (2010) used a Matrix Algebra approach to assess the efficiency of refining different types of lignocellulosic biomass. In Cherubini and Jungmeier (2010), the focus was instead on a switchgrass biorefinery. Boldrin et al. (2010) instead focused on the environmental assessment of a rapeseed-based biorefinery. Techno-economical evaluations were reported (among others) by Mao et al. (2010) and Villegas and Gnansounou (2008). However, the main focus of all these studies 
was agricultural residues and other biomasses. No relevant studies on solid waste refineries were found in the scientific literature.

The objective of this paper was to evaluate the environmental sustainability using lifecycle assessment of a specific waste refinery concept in which organic waste materials are liquefied using enzymes and recoverable materials are separated out in a "solid fraction". The assessment is based on experiments at a pilot-scale facility and includes a range of scenarios with specific focus on energy production and material recycling. This includes evaluation of i) mass and energy flows in the refinery processes, ii) environmental impacts related to the refinery processes itself, and iii) the overall sustainability aspects including downstream use of recovered materials and produced energy.

\section{Methodology}

\subsection{Waste composition}

The waste refinery process targeted residual municipal solid waste (MSW), i.e. the fraction remaining after source segregation in the households of the recyclable fractions such as paper, glass, metal, plastic, etc. As source segregation is not $100 \%$ efficient, recyclable materials were still present in the residual fraction. However, if organic waste is not source segregated the residual fraction proves to be wet and difficult to sort at high efficiencies. In Denmark, all residual MSW is collected separately and sent to waste incineration. The waste refinery process reported focused on treating this waste as an alternative to waste incineration, thereby recovering recyclable materials from a waste fraction that was not previously subjected to sorting prior to incineration. The waste composition has been shown in Table 1 alongside average values for similar waste in Europe.

Table 1

\subsection{Waste refinery}

The assessment was based on a pilot-scale facility established at a Danish incinerator (Amagerforbrænding, DK). The waste refinery had a treatment capacity of 1 tonne ww/h and had been in operation from January 2010 (see Figure 1). The refinery process consisted of two reactors: 1) in the first reactor the waste was heated by steam injection to about $95{ }^{\circ} \mathrm{C}$ for approximately 0.5 hours, then cooled to about $50-55^{\circ} \mathrm{C}$ before entering the second reactor. 2 ) 
In the second reactor enzymes were added resulting in hydrolysis and break-down of bonds in the organic materials thereby essentially suspending organic materials in the liquid phase. After the second reactor, the liquid phase was separated from the remaining solids.

Waste was fed through a hopper to the first reactor which was a cylindrical drum. Water was added to maintain sufficient moisture content, and improve mixing of the waste. The heated waste was dewatered after the first reactor (water content of about $60-70 \%$ by weight), thereby allowing partial recirculation of water in the reactor. The second reactor was also a cylindrical drum. The residence time in this reactor was within 8-16 hours depending on process configuration. $24 \mathrm{~kg}$ of enzymes were added per tonne of waste (this value can change as a consequence of the process optimization). A detailed description of the enzymatic processing can be found in Jensen et al. (2010). Both reactors were insulated to minimize heat loss and equipped with auxiliary electrical heating for compensation. After the second reactor, separation of liquid and solid fractions was done by a sequence of vibrating screens which included: washing of the solid fraction to improve the separation. The energy consumption for operation of the first reactor was $1.1 \mathrm{kWh}_{\mathrm{el}} /$ tonne ww (4 MJ/tonne ww), addition of steam ( 5 bar) accounted for another $580 \mathrm{MJ}_{\mathrm{th}} /$ tonne. Corresponding energy of 4.7 $\mathrm{kWh}_{\mathrm{e}} /$ tonne ww (17 MJ/tonne $\mathrm{ww}$ ) was consumed for the dewatering of the waste by a vibrating screen and water recirculation. Subsequent cooling of the waste accounted for about $4.7 \mathrm{kWh}_{\mathrm{el}} /$ tonne ww. The energy consumption for operation of the second reactor was 5.3 $\mathrm{kWh}_{\mathrm{el}} /$ tonne ww (19 MJ/tonne $\left.\mathrm{ww}\right)$ while the following separation of the output into a liquid and solid fraction amounted to a further $4.7 \mathrm{kWh}_{\mathrm{el}} /$ tonne ww. The final sieving included the pressing of the solid material to increase the recovery rate of the liquid fraction as well as dewatering the solids. All the energy data was based on process data from the operation of the pilot-scale plant on residual municipal solid waste. In total, the waste refinery process consumed about $33 \mathrm{kWh}$ el tonne ww and $580 \mathrm{MJ}_{\text {th }} /$ tonne ww (as heat).

The outputs from the waste refinery process per 1 tonne of treated residual waste were $1023 \mathrm{~kg}$ of liquid fraction (total solids (TS) 30\%) and $470 \mathrm{~kg}$ of solid fraction (57\% TS). The chemical composition of liquid and solid fraction is reported in Table 2. These values are to be considered as a result of preliminary investigations and can change following the future plant development and process optimization. The liquid fraction consisted primarily of suspended organic matter (food waste and paper), while the solid fraction mainly consisted of non-degradable materials such as glass, plastic, metals, textiles, soil, ceramics, etc. In these pilot-scale experiments, recyclable materials were hand-sorted from the solid fraction with the following estimated recoveries: glass (85\%), ferrous metals (85\%), and non-ferrous 
metals $(60 \%$, assumed to be aluminium). Similar recoveries have been reported in other studies on waste (e.g. Rigamonti \& Grosso, 2009; Arena et al., 2003). Energy consumption for the separation of recyclable materials was estimated at $18 \mathrm{kWh}_{\mathrm{el}} /$ tonne waste treated. Upgrading of the liquid fraction for fuel quality prior to co-combustion in power plants (see later description of assessment scenarios) was carried out by drying the materials reaching a calorific value of 14.5-15 GJ/tonne (85\% TS). The drying was estimated to consume additional $402 \mathrm{MJ}_{\mathrm{th}} /$ tonne $\mathrm{ww}$.

Figure 1

Table 2

\subsection{Goal and scope of the assessment}

The functional unit of the life cycle assessment (LCA) was "treatment of one tonne (1000 kg) of Danish residual municipal solid (wet) waste". The chemical composition of the waste was assumed to be identical to the average Danish residual household waste as reported by Riber et al. (2009).

The assessment considered the waste as a "zero-burden" boundary (i.e. the waste as such was not assumed to carry any environmental impacts). Downstream utilization of recovered heat/electricity and recyclable materials were credited the system by system expansion into the energy and industrial sectors (saved production of energy and virgin materials). The boundary of the system was set at the treatment facility gate (incinerator and waste refinery) and included downstream disposal of incineration ashes and recycling of materials. The impacts related to waste collection were excluded from the assessment as they contributed equally to all scenarios. Also the environmental impacts associated with the construction and demolitions of facilities were not included. Following common practices in LCA studies, all environmental impacts (resource consumption, emissions to air, soil and water) related to the transportation and treatment (until final disposal) of the liquid and solid fractions, recyclables, bottom and fly ashes were included for a time horizon of 100 years. An overview of the LCA system boundary is presented in Figure 2.

\subsection{Impact assessment}

The assessment was carried out according to the LCA method EDIP 1997 (Wenzel et al., 1997) following the principles of consequential LCA (e.g. Finnveden et al., 2009), i.e. 
focusing on the consequences of a decision (in this case treatment of the waste previously mentioned). This for example means that energy generated by the waste system was assumed to substitute energy production at the plants which actually respond to the change, rather than substituting average energy production (Weidema et al., 1999). When system expansion was not applicable, for instance in the case of cogeneration of heat and electricity at combined heat and power plants (CHP), allocation based on energy quality (exergy) was instead applied according to that of Fruergaard et al. (2010).

The following impact categories were included in the assessment: Global Warming (GW), Acidification (AC), Nutrient Enrichment (NE), Ecotoxicity in water chronic (ETwc), Human Toxicity via water (HTw), Human Toxicity via soil (HTs), Human Toxicity via air (HTa).

\subsection{LCA scenarios}

The life cycle assessment included two sets of scenarios: 1) various approaches for energy utilization of outputs from the waste refinery, and 2) various configurations of the surrounding energy system reflecting a range of assumptions regarding downstream energy substitution.

\subsubsection{Waste refinery scenarios}

Five different scenarios for the treatment of the residual municipal solid waste were evaluated:

1) INC: All waste was incinerated. Recycling of ferrous metals and aluminium separated from incineration ashes.

2) CC-CC: Co-combustion of the liquid and solid fractions after drying, and recycling of glass, ferrous metals, and aluminium.

3) CC-INC: Co-combustion of the liquid fraction after drying, incineration of the solid fraction, and recycling of glass, ferrous metals, and aluminium.

4) BG-CC: Anaerobic digestion of the liquid fraction, co-combustion of the solid fraction after drying, and recycling of glass, ferrous metals, and aluminium. Biogas was assumed combusted in a gas-fired combined heat and power plant, generating heat and electricity.

5) BG-INC: Anaerobic digestion of the liquid fraction, incineration of the solid fraction, and recycling of glass, ferrous metals, and aluminium. Biogas was assumed to be 
combusted in a gas-fired combined heat and power plant, generating heat and electricity.

Figure 2

\subsubsection{Energy system scenarios}

Special attention was devoted to assumptions regarding the surrounding energy system as choices here may significantly affect the outcome of the LCA (Fruergaard et al., 2009, Fruergaard \& Astrup, 2010; Finnveden et al., 2009, Ekvall \& Weidema, 2004, Weidema et al., 1999). In a short term perspective (e.g. within the coming 5-15 years), it can be assumed that the existing energy production capacities respond to changes in the waste sector according to their relative share of the energy production. In a longer term perspective (e.g. beyond 15 years), it may be assumed that energy from waste contributes to the decommissioning of fossil based energy production capacities (both electricity and heat) as these technologies are generally intended to be phased out in order to comply with political $\mathrm{CO}_{2}$ reduction targets. Of the fossil fuels, coal and natural gas represent the two ends of the range with respect to $\mathrm{CO}_{2}$ emissions per combustion unit of fuel energy $\left(95 \mathrm{~kg} \mathrm{CO}_{2} / \mathrm{GJ}\right.$ coal and $56.77 \mathrm{~kg} \mathrm{CO}_{2} / \mathrm{GJ}$ natural gas). While electricity production from waste can be considered marginal compared with the total electricity production in most countries, substitution of district heating often depends on local conditions and production capacities connected to the district heating network in question (Fruergaard et al., 2010). This means that when evaluating a system in a short term perspective involving existing production capacities, substitution of district heating should reflect local conditions. However, it is viable to assume that in the long term heat production from waste will contribute to phasing-out fossil fuels.

In this study, five different energy systems were evaluated for each waste refinery scenario. One energy system reflected the current situation (short term) in Copenhagen as an example of a complex district heating system, while the four additional systems reflected a long term perspective with and without heat recovery:

1) ST-CPH (Short Term - Copenhagen): Electricity from waste incineration was assumed to substitute electricity production at coal-fired power plants and heat production was assumed to substitute a mix of the following fuels representing district heating production in the Copenhagen area: coal (11.4\%), fuel oil (4.8\%), natural gas (18.6\%), straw and wood pellets (23.1\%). Co-combustion of the liquid and solid fractions was in 
this case assumed to directly replace coal at the existing CHP plants. Similarly, biogas was assumed to directly replace natural gas also at CHP plants. Consequently, no changes in energy production from these plants were assumed and energy substitution only concerned fuel consumption at the plants.

2) LT-CO (Long Term - Coal): Electricity and heat production from waste was assumed to substitute production at coal-fired CHP plants (allocation according to energy quality).

3) LT-NG (Long Term - Natural Gas): Electricity and heat production from waste was assumed to substitute energy production at natural gas fired CHP plants (allocation according to energy quality).

4) LT-CONH (Long Term - Coal, No Heat): Electricity production from waste was assumed to substitute production at coal-fired CHP plants (allocation according to energy quality). No heat recovery was assumed.

5) LT-NGNH (Long Term - Natural Gas, No Heat): Electricity production from waste was assumed to substitute production at natural gas fired CHP plants (allocation according to energy quality). No heat recovery was assumed.

The last two energy scenarios without heat recovery were included to better illustrate the importance of district heating and provide scenarios better reflecting the situation in countries with significantly less heat recovery from waste.

\subsection{Associated technologies}

\subsubsection{Waste incineration}

Waste incineration was modelled as a grate-fired incinerator equipped with wet flue gas cleaning, selective non-catalytic reduction (SNCR) of $\mathrm{NO}_{\mathrm{x}}, \mathrm{Hg}$ and dioxin removal by activated carbon. Gross electricity and heat efficiencies of the incinerator were $20 \%$ and 65 $\%$, respectively, relative to the lower heating value (LHV) of the waste input. These are considered average values for Denmark (Fruergaard \& Astrup, 2010). Internal electricity consumption at the plant was $65 \mathrm{kWh} /$ tonne of waste plus an additional $0.42 \mathrm{~L} /$ tonne of oil as auxiliary fuel, and $0.66 \mathrm{~kg} \mathrm{NaOH} /$ tonne and $7.85 \mathrm{~kg} \mathrm{CaCO}_{3} /$ tonne for flue gas cleaning (Astrup et al., 2009; Fruergaard \& Astrup, 2010).

Following the approach of Riber et al. (2008), emissions were divided into either process-specific emissions (emissions independent of waste composition but proportional to the amount of waste incinerated) or waste-specific emissions (determined by output transfer 
coefficients). Selected air emissions are shown in Table $3.119 \mathrm{~kg}$ of bottom ashes, $17 \mathrm{~kg}$ of fly ashes and other $12 \mathrm{~kg}$ APC (Air Pollution Control) residues were generated per tonne of waste. Magnetic and non-magnetic metals were recovered from bottom ashes (overall recovery estimated at $38 \%$ ) prior to utilization as construction material substituting natural gravel (Birgisdottir et al., 2007). APC residues were assumed to be utilized in the backfilling of old mines (Fruergaard et al., 2010).

\subsubsection{Coal-fired CHP plant}

Co-combustion of liquid and solid fractions from the waste refinery were modelled as a coalfired CHP plant. The plant was suspension fired with pulverized coal and equipped with semi-dry flue gas cleaning and selective catalytic reduction (SCR) of $\mathrm{NO}_{\mathrm{x}}$ (Fruergaard \& Astrup, 2010). Net electricity and heat efficiencies of the incinerator were both $40 \%$ (DONG, 2008), relative to the lower heating value (LHV) of the waste input. Reagents for flue gas cleaning amounted to $19 \mathrm{~kg} \mathrm{CaO} /$ tonne, $1 \mathrm{~kg} \mathrm{NH}_{3} /$ tonne, $0.21 \mathrm{~kg} \mathrm{NaOH} /$ tonne and $0.14 \mathrm{~kg}$ HCl/tonne (Astrup et al., 2009; Fruergaard \& Astrup, 2010). Selected air emissions are shown in Table $3.175 \mathrm{~kg}$ of bottom ashes, $20 \mathrm{~kg}$ of fly ashes, and $13 \mathrm{~kg}$ of air-pollutioncontrol (APC) residues were generated per tonne of waste co-combusted. Fly ash was assumed to be used for backfilling of old salt mines while the remaining solid residues were assumed to be landfilled following the approach of Fruergaard et al. (2010).

Prior to co-combustion, the liquid fraction was assumed to be dried to reach a LHV of about $15 \mathrm{GJ} /$ tonne with a total solid content of $85 \%$ TS. The energy consumption associated with drying was estimated to be $112 \mathrm{MJ}_{\mathrm{th}} /$ tonne ww (402 $\mathrm{kWh}_{\mathrm{th}} /$ tonne ww).

Table 3

\subsubsection{Anaerobic digestion}

The liquid fraction was assumed to be digested using a one stage mesophilic anaerobic digestion plant appropriate for organic municipal solid waste (Boldrin et al., 2010). A methane yield corresponding to $75 \%$ of the methane potential of the liquid fraction was assumed, in agreement with similar practice for organic waste (Davidsson et al., 2007, Pognani et al., 2009 and Møller et al., 2010). The methane content in the biogas was assumed to be $63 \%$ (vol.). Internal energy consumption at the plant was: $0.9 \mathrm{~L}$ of diesel and $18 \mathrm{kWh}$ of electricity per tonne of wet waste received at the plant. The electricity consumption was considerably lower than typical plants treating organic waste because the slurry did not 
require typical pre-treatment such as shredding, sieving, plastic/metal removal and hydrolysis. The dry matter content of the digestate was set to $10 \%$ based on a mass balance on the system. Overall, $84 \mathrm{Nm}^{3} \mathrm{CH}_{4}\left(133 \mathrm{Nm}^{3}\right.$ biogas) and 2.2 tonnes of digestate (10\% TS) were generated per tonne of liquid fraction. Any reject appearing was neglected. Fugitive methane emissions were assumed controlled by appropriate air controls and a flare (Boldrin et al., 2010).

\subsubsection{Natural gas-fired CHP plant}

Combustion of biogas generated by anaerobic digestion was assumed to occur in a gas-fired combined heat and power plant. The inventory of resource consumption was assumed to be the same as described for the coal-fired power plant. The energy efficiency was assumed equal to the coal-fired CHP plant (i.e. $40 \%$ electricity and $40 \%$ heat recovery based on the LHV of the biogas). The main air emissions associated with biogas combustion were: $\mathrm{SO}_{2}=0.11 \mathrm{~g} / \mathrm{Nm}^{3}$ biogas, $\mathrm{NO}_{\mathrm{x}}=3 \mathrm{~g} / \mathrm{Nm}^{3}$ biogas, $\mathrm{CH}_{4}=1.8 \mathrm{~g} / \mathrm{Nm}^{3}$ biogas, $\mathrm{N}_{2} \mathrm{O}=0.0028 \mathrm{~g} / \mathrm{Nm}^{3}$ biogas (Nielsen \& Illerup, 2006).

\subsubsection{Recycling of glass, metals and plastic}

Glass recycling was assumed to substitute $99 \%$ virgin production through re-melting of cullet and with a market substitution ratio of $100 \%$ for the produced glass. Glass recycling included the production of glass from cullet minus the avoided virgin production. Savings in providing virgin resources for glass production was not included (Larsen et al., 2009 and DTU Environment, 2008). The benefit of glass recycling was primarily related to savings in energy consumption, corresponding to a new saving of $230 \mathrm{~kg} \mathrm{CO}_{2}$ - eq/tonne of glass input.

Ferrous metal recycling was assumed to substitute $100 \%$ virgin production with a market substitution ratio of $100 \%$ for the produced metal. Metal recycling included remelting of scraps and rolling of new steel sheets from the melted metal waste, minus the avoided virgin production (Larsen et al., 2009 and DTU Environment, 2008). The benefit of metal recycling was primarily savings in energy consumption, corresponding to a net saving of $1689 \mathrm{~kg} \mathrm{CO} 2$-eq/tonne of metal input.

Aluminium recycling was assumed to substitute $100 \%$ virgin production with a market substitution ratio of $100 \%$ for the produced aluminium. An overall material loss of $21.2 \%$ was assumed due to the sorting process. Aluminium recycling included re-melting of aluminium scrap and alloying, minus the avoided virgin production (Larsen et al., 2009 and 
DTU Environment, 2008). The benefit of aluminium recycling was primarily savings in energy consumption, corresponding to a net saving of $7698 \mathrm{~kg} \mathrm{CO}_{2}$ - eq/tonne of metal input.

Plastic recycling was assumed to substitute $90 \%$ virgin production by re-melting with a market substitution ratio of $90 \%$. The latter value was a rough estimate of the potential decrease in material quality. According to Schmidt \& Stromberg (2006), the loss of material quality can be as high as $20 \%$. However, they also stated that the loss highly depends on the field of application of the secondary plastic. For instance, in the case that the recovered plastic is utilized as an admixture in the production of primary plastic there may be no loss. Thus, in this study, $10 \%$ loss in material quality was assumed. Plastic recycling included the granulation and re-melting for production of PE plastic from waste plastic minus the avoided virgin production (DTU Environment, 2008). The benefit of plastic recycling was primarily savings in energy consumption, corresponding to a net saving of $644 \mathrm{~kg} \mathrm{CO}$-eq/tonne of plastic input.

\subsubsection{Transportation}

The fuel consumption for transport of the liquid and solid fraction as well as of the residues from incineration, combustion and anaerobic digestion (i.e. bottom and fly ash, APC and digestate) was represented by "transportation" to the point of unloading, e.g. at the treatment or disposal facilities. The fuel consumption was expressed in fuel consumption per tonne of waste per km (one-way-distance) according to Eisted et al. (2009). Transport distances for the liquid and solid fractions between the waste refinery and downstream utilization were assumed to be $15 \mathrm{~km}$ based on Danish conditions. Transport distances related to solid residues from incineration and co-combustion were assumed to be $70 \mathrm{~km}$ for bottom ashes and $500 \mathrm{~km}$ for APC residues and fly ashes. As recyclables generally enter a global market, transport distances were unknown in this case but average European values were used for approximation (Eisted et al., 2009): $100 \mathrm{~km}$ for glass and plastic and $500 \mathrm{~km}$ for aluminium and ferrous metals.

\section{Results and discussion}

The results of the Life-cycle impact assessment (LCIA) are reported in Figure 3 to 4 and Table 5 to 7 . The results of the LCIA are expressed as normalized impact potentials in the unit milliPerson Equivalent (mPE) per tonne ww. EU 15 normalization references have been used in the normalization step (Table 4). One PE corresponds to the environmental load 
caused by one average EU 15 citizen in one year (reference year: 1990) covering all activities in life (mining, agriculture, transport, housing, etc.).

Table 4

\subsection{Environmental performance of the waste refinery}

Evaluating the waste refinery process, without considering the system context, can provide information about which sub-processes are most important. Figure 3 shows the potential impacts related to Global Warming (GW), Acidification (AC), and Nutrient Enrichment (NE) for two of the energy system scenarios: LT-CO and LT-NG. Only the environmental categories $\mathrm{GW}, \mathrm{AC}$ and $\mathrm{NE}$ were considered for discussion as the other environmental and toxic categories proved negligible. Only the two energy system scenarios LT-CO and LT-NG were addressed. The results can be considered representative also for the other energy scenarios. The main impacts associated with GW were related to the production of enzymes (4.4 kg CO $2-e q / k g$ of enzyme, corresponding to $12 \mathrm{mPE} /$ tonne ww treated). Electricity and heat consumption (respectively equal to $33 \mathrm{kWh}_{\mathrm{e}} /$ tonne $\mathrm{ww}$ and $580 \mathrm{MJ}_{\text {th }} /$ tonne $\mathrm{ww}$ ) contributed with smaller loads (the magnitude depended on whether coal or natural gas was substituted). For the scenarios including co-combustion (CC-CC and CC-INC), drying of the liquid fraction contributed with an additional 11 and $1.5 \mathrm{mPE} /$ tonne ww treated in the coal and natural gas scenarios, respectively. This means that the load due to energy consumption in the drying process may be as high as the impact caused by enzyme production in case of coal energy substitution (i.e. LT-CO).

The impacts on the category $\mathrm{AC}(6-8 \mathrm{mPE} /$ tonne ww) were again related to the energy consuming processes such as drying of the liquid fraction and industrial production of enzymes (release of $\mathrm{SO}_{2}$ and $\mathrm{NO}_{\mathrm{x}}$ from combustion).

Industrial production of enzymes contributed with a significant environmental load on the Nutrient Enrichment (NE) category due to the release of nutrients in the forms of $\mathrm{NO}_{\mathrm{x}}$ and phosphates to water (approximately $15 \mathrm{mPE} /$ tonne ww). This was in accordance with other similar results found in the literature (Nielsen et al., 2007).

Overall, to optimize the waste refinery process focus should be directed to the consumption of energy and enzymes.

Figure 3 


\subsection{Short term perspective}

The short term perspective reflects the current boundary conditions in the Copenhagen area and was evaluated as an example of implementing the waste refinery concept in an existing district heating system with significant shares of biomass. Results for the five waste management scenarios are shown in Figure 4 (non-toxic and toxic categories). In order to simplify the discussion, the net numerical values are presented in Table 5.

\subsubsection{Non-toxicity impact categories}

Impacts related to GW were in the five scenarios strongly correlated with the energy recovery at the incinerator or CHP plant and the corresponding energy substituted (and savings in $\mathrm{CO}_{2}$ emissions). The co-combustion scenario (CC-CC) appeared to have the best performance (-81 $\mathrm{mPE} /$ tonne ww) due to the high electricity efficiency of the CHP plant. As part of the district heating generated in the incineration scenario (INC) substituted biomass resources, which were considered $\mathrm{CO}_{2}$ neutral within the short term perspective, this scenario appeared less competitive (-13 mPE/tonne ww) compared with the other scenarios. A consequence of substituting heat production at back-pressure CHP plants (the biomass CHP plants in the Copenhagen area) is a decreased electricity production at the same plants. This requires that other plants "deliver" the electricity deficit to maintain system comparability thereby inducing an additional environmental load (Fruergaard et al., 2010). It was assumed that this electricity was marginal and produced based on coal, following the approach of Fruergaard et al. (2010). An important assumption for the context was that biomass resources were not considered constrained. Thus, the biomass resources saved by substitution of heat at biomass plants were not assumed to be used elsewhere to off-set fossil fuels. This can be debated; however, the assumption was used here to illustrate a situation in which biomass was readily available on an international market. The alternative situation in which biomass is a constrained resource, and any biomass saved will thus be used elsewhere to off-set fossil fuels, is covered by the long term perspective in this paper (the fossil fuels being either coal or natural gas). The difference between energy recovery for the INC scenario in the short term perspective and the long term perspective thereby illustrates the importance of this assumption.

The importance of co-combusting the solid fraction relative to incineration was illustrated by the difference found between the CC-CC and CC-INC scenarios, i.e. about 41 $\mathrm{mPE} /$ tonne ww. The biogas scenario (BG-CC) with co-combustion of the solid fraction showed savings similar to the CC-INC scenario (-36 mPE/tonne ww). As with the scenario in 
which the liquid fraction is co-combusted, it was found that again incinerating the solid fraction resulted in smaller savings (BG-INC) compared to co-combustion.

The results for AC followed the same overall trend as $\mathrm{GW}$ because the relevant emissions (nitrogen oxides and sulphur dioxide) are also related to energy production. Nutrient Enrichment (NE) showed a different trend as application of digestate on soil after anaerobic digestion of the liquid fraction led to significant loads. This is because use of digestate on land increased $\mathrm{NO}_{3}{ }^{-}$and $\mathrm{PO}_{4}{ }^{3-}$ leaching compared with application of inorganic fertilizers. This was in agreement with the results of other studies on anaerobic digestion (Sander et al., 2003).

\subsubsection{Toxicity impact categories}

The impacts related to Ecotoxicity in water (ETwc) were mainly related to the recycling rates of aluminium (60\%) and ferrous metals (85\%). The higher recycling rates found in the waste refinery scenarios induced greater savings compared with incineration (INC). This was principally due to avoided emissions from virgin metal production (Polycyclic Aromatic Hydrocarbons, i.e. PAHs, $\mathrm{Fe}, \mathrm{Cd}, \mathrm{Sr}$ ) as well as the associated energy savings (especially with respect to aluminium production).

For Human Toxicity via soil (HTs), the environmental impacts primarily originated from $\mathrm{As}$ and $\mathrm{Hg}$ emissions to soil from the application of digestate to farmland (scenarios BG-CC and BG-INC). Also, to a smaller extent from $\mathrm{Hg}$ emissions to air from the combustion processes. $\mathrm{Hg}$ emissions to air were also the main contribution responsible for impacts related to Human Toxicity via water (HTw). In this category, better flue gas cleaning at the waste incinerator (including $\mathrm{Hg}$ removal) allowed an improved environmental performance compared with the scenarios involving co-combustion of the solid fraction (CCINC, BG-INC).

\subsection{Long term perspective}

The long term perspective is not related to a specific district heating network or a specific geographic area. Instead, it reflects a potential future situation in which waste contributes to the transition away from fossil fuels by substituting fossil fuels such as coal or natural gas. The results are shown in Figure 4. In Table 5 the net numerical results are reported.

\subsubsection{Non-toxicity impact categories}


The performance of the five assessed scenarios with respect to GW was again related to energy recovery (particularly electricity) at the power plant or the incinerator, as shown in Figure 4 and Table 5. The assumption regarding the marginal energy substituted (either coal or natural gas) played a critical role with respect to the magnitude of the results. However, this choice did not change the overall ranking of the scenarios. The scenario in which the solid and liquid fraction was co-combusted (CC-CC) achieved the best environmental performance (savings equalled -106 and -44 mPE/tonne ww in LT-CO and LT-NG, respectively). The scenario which includes anaerobic digestion of the liquid fraction and cocombustion of the solid fraction (BG-CC) gave comparable results with the reference scenario (incineration). In fact, even though the energy efficiency was found to be higher in the scenario involving biogas production and co-combustion (BG-CC) as demonstrated in the energy balance in Table 6 , the environmental load caused by the waste refinery itself decreased the overall benefits. This was found to be the case for all the options including the refining process. Finally, the lower electricity recovery at the incinerator made the option of incinerating the solid fraction less attractive compared to co-combustion in power plants (Figure 4).

As already discussed for the short-term perspective, the trend for AC followed the results reported for the GW category. However, the NE impact category proved to be contrary to this as the application of digestate on land led to significant impacts due to increased leaching of nutrients compared to the use of inorganic fertilizers.

\subsubsection{Toxicity impact categories}

The benefits found with the ETwc impact category (Figure 4) were principally related to the recycling rates of aluminium and ferrous metals. As already discussed for the short-term perspective, the higher efficiency of recycling in the waste refinery induced higher environmental savings compared with incineration. This was the case for all options including the refining process.

Significant environmental loads (approximately 155-214 mPE/tonne ww), associated with the scenarios in which the liquid fraction is sent to anaerobic digestion (BG-CC and BGINC), were found for the Human Toxicity via soil (HTs) category. The impacts were primarily caused by As and $\mathrm{Hg}$ emissions to soil from digestate application. However, this data was determined by modelling in EASEWASTE and experimental data is needed in order to evaluate the quality of the digestate in more detail. 
Finally, with regards to the HTw category, it was found that better removal of $\mathrm{Hg}$ during the flue gas cleaning in the incinerator allowed for an improved environmental performance for the applicable scenarios, for example, the incineration of the solid fraction (CC-INC and BG-INC) compared to those scenarios in which the solid fraction is cocombusted (CC-CC and BG-CC).

Figure 4

Table 5

\subsection{The significance of heat production}

The co-generation of heat and electricity is strictly connected to local conditions such as the presence of a district heating network and an existing demand for heat throughout the year. Consequently, two management scenarios without heat production (LT-CONH and LT$\mathrm{NGNH}$ ) were evaluated in order to show the significance of heat production on the overall results. In general the results showed that, whenever heat was not co-generated or utilized in the incinerator or power plant, all waste refinery management scenarios achieved a better environmental performance compared to incineration (INC), see Figure 4 and Table 5. This was found to be especially true with respect to GW (Figure 4). The opportunity of generating a high quality energy carrier, such as electricity, from solid and liquid fractions, was associated with significant environmental savings in all the scenarios including the waste refinery (CC-CC and BG-CC in particular). The magnitude of the environmental benefits was higher when substituting coal-based energy than natural gas-based, a consequence of the $\mathrm{CO}_{2}$ emissions associated with the production and combustion of the fuel.

With regards to $\mathrm{AC}$, the trend was the same as for GW. However, this pattern was not found with the other environmental impact categories. The other results including the ranking of the scenarios were similar to the energy scenarios assuming heat production.

\subsection{Energy balance}

An energy balance was carried out in order to evaluate the energy efficiency and related performance of the assessed waste management scenarios. The balance accounted for all the energy-related inputs and outputs (electricity, heat, fuels, including energy required to extract and produce the fuel) to and from the systems during the entire life-cycle of the waste. The heat and electricity generated from the scenarios were assumed to substitute coal or natural gas marginal heat/electricity. In case of CHP plants, the energy recovered in the form of heat 
was calculated based on the exergy content (0.15), in accordance with Fruergaard et al. (2009). Substitution of fertilizers and related energy savings were also included.

As shown in Table 6, the ranking of the scenarios followed the results achieved for the Global Warming category $(\mathrm{GW})$, confirming that energy recovery (particularly electricity) was most important to GW, as previously discussed. The best energy performance (-15.9 GJ/tonne ww in the coal scenario and $-13.9 \mathrm{GJ} /$ tonne ww in the natural gas scenario) was achieved with co-combustion of the two fractions (CC-CC). The scenario including anaerobic digestion of the liquid fraction and co-combustion of the solid fraction (BG-CC) achieved similar performances of incineration $(-11.1 \mathrm{GJ} /$ tonne ww in the coal scenario and 7.5 GJ/tonne ww in the natural gas scenario).

As shown in Table 6, energy recovery at the CHP plant was the most important energy saving whereas the most important energy expenses were related to the waste refinery and to the (eventual) drying process. The waste refinery contributed with an energy consumption of between 3.4 and $3.8 \mathrm{GJ} /$ tonne ww depending on the fuel substituted. The production of enzymes was the most energy-intensive process (about $1.4 \mathrm{GJ} /$ tonne ww). The drying process was estimated to require between 0.3 and $1.9 \mathrm{GJ} /$ tonne ww depending on fuel substituted. Among the recycling processes, aluminium recycling contributed with the most significant energy savings (about $-0.7 \mathrm{GJ} /$ tonne ww).

Table 6

\subsection{Sensitivity analysis}

A sensitivity analysis was produced in order to evaluate the influence of relevant assumptions and parameters in the assessment. The analysis focused on the following key assumptions of the study: waste composition, impacts related to industrial production of enzymes, potential for plastic recycling, methane potential of the liquid fraction, recycling rates in the waste refinery system and utilization of the biogas in more efficient integrated gas combined cycle (IGCC) facilities. For the sensitivity analysis, only the results for the energy system LT-CO based on coal as marginal energy were reported (Table 7). This was because the results indicated the same trend for all the other energy scenarios.

A different waste composition (Christensen et al., 2009) was used in order to assess the performance of the scenarios with a waste composition typical of MSW without sourcesegregation (Table 1). Consequently, this allowed an assessment of the influence of a higher content of metals and paper in the total mixed waste on the environmental impact categories. 
The results (Table 7) showed a significant increase in savings in ETwc thanks to the higher amounts of recyclables produced. While at the same time increased environmental loads for the toxicity categories (HTw and HTs) were found. This was primarily because of increased emissions of $\mathrm{Hg}, \mathrm{Cd}, \mathrm{Cr}$ and other heavy metals to the air and soil through co-combustion and digestate application on soil. As shown in Table 7, the scenarios including incineration of the solid fraction (CC-INC and BG-INC) achieved a better performance in these categories thanks to the improved flue-gas cleaning system (stricter emissions regulations). In the nonToxic categories (e.g. GW and AC) the difference compared with the baseline scenario was negligible.

A sensitivity analysis was also performed on the impacts related to the industrial production of enzymes. An annual decrease of $5 \%$ on the $\mathrm{CO}_{2}$ emissions from enzymes production is expected based on the sustainability targets of the producers (Novozymes $\mathrm{A} / \mathrm{S}$, 2004). Thus, the impact of the enzymes production was decreased from 4.4 to $2 \mathrm{~kg} \mathrm{CO}_{2^{-}}$ eq/kg enzyme (e.g. 15-20 years from the current situation). Alternatively, this corresponds to an input of $10 \mathrm{~kg}$ enzymes/tonne ww in the current situation (instead of $24 \mathrm{~kg} /$ tonne ww). As shown in Table 7, the lower environmental cost of enzymes production was crucial in amplifying the difference in the GW impact between the reference (INC) and the management scenarios involving the waste refinery. Reducing the environmental cost of enzyme production increased the savings in GW by approximately $-8 \mathrm{mPE} /$ tonne ww (i.e. 70 $\mathrm{kg} \mathrm{CO}$-eq/tonne ww).

The opportunity for plastic recycling (the recovery rate was assumed equal to $21 \%$ ) turned out not to be significant from an environmental point of view. The little amount of recyclable plastic found in the waste composition (about $15 \mathrm{~kg} /$ tonne ww) together with the high savings associated with the opportunity of co-combusting the solid fraction made the latter option preferable compared to recycling.

The efficiency of the digestion process was found to be extremely relevant with respect to GW. In the sensitivity analysis, the degradation of volatile solids (VS) was set to $60 \%$ (i.e. $67 \mathrm{Nm}^{3} \mathrm{CH}_{4} /$ tonne liquid fraction) and $90 \%$ (i.e. $100 \mathrm{Nm}^{3} \mathrm{CH}_{4} /$ tonne liquid fraction) (instead of $75 \%$ as it was assumed in the baseline scenario). The results (Table 7) showed a net difference compared with the baseline scenario of about $\pm 7 \mathrm{mPE} /$ tonne ww.

A lower recycling rate (assumed equal to $50 \%$ for all materials) for glass, aluminium and ferrous metals in the waste refinery led to decreased environmental benefits in the GW and ETwc categories. Lower the recovery, lower the substitution of virgin resources and related extraction-production processes. This induced further energy consumption as well as 
emissions contributing to impacts on GW and ETwc. Furthermore, a decreased recycling rate led to an increase in the emissions of metals from the co-combustion process contributing to higher environmental loads in the toxicity categories (HTs and HTw).

Finally, the biogas was assumed to be utilised in IGCC instead of a gas-fired power plant. This assumption was carried out in order to assess the influence of a higher electricity recovery rate on the result. Net electricity and heat efficiencies were set to $60 \%$ and $30 \%$ (per LHV of the biogas) according to DEA (2005). With this option, the savings in GW were increased by about $12 \mathrm{mPE} /$ tonne ww (i.e. $104 \mathrm{~kg} \mathrm{CO}$-eq/tonne ww).

Overall, the sensitivity analysis demonstrated that the optimization of the waste refinery (with downstream energy utilizations) was primarily related to metals and energy recovery (including optimization of biogas production) as well as the opportunity of decreasing enzymes consumption.

\section{Table 7}

\section{Conclusions}

Four different waste management scenarios involving enzymatic refining of residual MSW were evaluated and compared with a reference (incineration). This was modelled across five different energy systems scenarios including the substitution of coal- and natural gas-based energy production.

The results of the study demonstrated that enzymatic refining of the waste with utilization of the products for energy recovery can represent a valuable alternative to incineration from both an energy and environmental point of view. This is the case if the downstream energy options for exploiting the solid and liquid fractions are co-combustion and anaerobic digestion for biogas production. The principal savings of the waste refinery process were related to higher metals and energy recovery (particularly with respect to electricity) compared to that of incineration. Improvement in the environmental as well as energy performance of the waste refinery itself was primarily related to the optimization of energy and enzymes consumption.

The sensitivity analysis revealed that low recycling rates for metals (under 50\%) and low methane potential of the liquid fraction (under $70 \%$ VS degradation) would cancel the savings gained by the waste refinery, including Global Warming and Acidification savings from biogas production. The results also emphasized that the final quality of the digestate for 
application on-land represents an important issue that has to be evaluated through further analyses and assessments.

\section{Acknowledgements}

The authors highly appreciated the contributions from Nanna Dreyer Nørholm and Per Lundqvist (DONG Energy) as well as the inputs from Per Henning Nielsen and Anne Merete Nielsen (Novozymes) regarding the production processes of enzymes. Financial support to this study was provided by the research grant PSO-7335 REnescience from Energinet.dk as well as Technical University of Denmark.

\section{References}

Arena, U., Mastellone, M.L. \& Perugini, F. (2003). The environmental performance of alternative solid waste management options: a life cycle assessment study. Chemical Engineering Journal, 96, 207-222.

Astrup, T., Møller, J. \& Fruergaard, T. (2009). Incineration and co-combustion of waste: accounting of greenhouse gases and global warming contributions. Waste Management \& Research 27, 789-799.

Birgisdottir, H., Bhander, G., Hauschild, M.Z. \& Christensen, T.H. (2007). Life cycle assessement of disposal of residues from municipal solid waste incineration: Recycling of bottom ash in road construction or landfilling in Denmark evaluated in the ROAD-RES model. Waste Management 27, S75-S84.

Boldrin, A., Balzan, A. \& Astrup, T. (2010). Life cycle assessment of a rapeseed-based biorefinery process. Biomass and Bioenergy (accepted for publication).

Boldrin, A., Neidel, T.L., Damgaard, A., Bhander, G.S., Møller, J. \& Christensen, T.H. (2010). Modelling of environmental impacts from biological treatment of organic municipal waste in EASEWASTE. Waste Management (accepted for publication)).

Cherubini, F. \& Ulgiati, S. (2010). Crop residues as raw materials for biorefinery systems - A LCA case study. Applied Energy, 87, 47-57. 
Cherubini, F. \& Jungmeier, G. (2010). LCA of a biorefinery concept producing bioethanol, bioenergy, and chemicals from switchgrass. Int J Life Cycle Assess, 15, 53-66.

Cherubini, F. \& Stroemann, A.H. (2010). Production of Biofuels and Biochemicals from Lignocellulosic Biomass: Estimation of Maximum Theoretical Yields and Efficiencies Using Matrix Algebra. Energy Fuels 24, 2657-2666.

Christensen, T.H., Simion, F., Tonini, D. \& Møller, J. (2009). Global warming factors modelled for 40 generic municipal waste management scenarios. Waste Management \& Research, 27, 871-884.

Clift, R., Doig, A. \& Finnveden, G. (2000). The Application of Life Cycle Assessment to Integrated Solid Waste Management Part 1-Meyhodology. IChem, 78, 279-287.

Directive 1999/31/EC of the European Parliament and of the Council of 26 April 1999 on the landfill of waste. EU Commission, Brussels.

Davidsson, Å., Gruvberger, C., Christensen, T.H., Hansen, T.L. \& Jansen, J.C. (2007). Methane yield in source-sorted organic fraction of municipal solid waste. Waste Management, 27, 406-414.

Danish Energy Authority (DEA) (2005). Technology Data for Electricity and Heat Generating Plants. http://www.ens.dk.

DONG (2008). Avedøreværket - Grønt regnskab 2008 (Avedøreværket - Green report, in Danish). www.dongenergy.com. Accessed March 2010.

DTU Environment (2008). EASEWASTE 2008 database (Environmental Assessment of Solid Waste Systems and Technologies). http://www.easewaste.dk/. Developed at Department of Environment Engineering, Technical University of Denmark, Kongens Lyngby, Denmark. 
Eisted, R., Larsen, A.W., \& Christensen, T.H. (2009). Collection, transfer and transport of waste: accounting of greenhouse gases and global warming contribution. Waste Management \& Research, 27, 738-745.

Ekvall, T. \& Finnveden, G. (2000). THE APPLICATION OF LIFE CYCLE ASSESSMENT TO INTEGRATED SOLID WASTE MANAGEMENT Part 2-Perspectives on Energy and Material Recovery from Paper. Energy, 78(July), 25-28.

Ekvall, T. \& Weidema, BP. (2004). System boundaries and input data in consequential life cycle inventory analysis. International Journal of Life Cycle Assessment, 9 (3), 161-71.

Eriksson O., Finnveden G., Ekvall T. \& Bjorklund A. (2009). Life cycle assessment of fuels for district heating: A comparison of waste incineration, biomass- and natural gas combustion. Energy Policy 35. 1346-1362.

Finnveden, G., Hauschild, M.Z., Ekvall, T., Guine, J., Heijungs, R., Hellweg, S., Koehler A., Pennington, D. \& Suh, S. (2009). Recent developments in Life Cycle Assessment. Journal of Environmental Management 91, 1-21.

Fruergaard, T., Ekvall, T. \& Astrup, T. (2009). Energy use and recovery in waste management and implications for accounting of greenhouse gases and global warming contributions. Waste Management \& Research, 27(8), 789-799.

Fruergaard, T., Hyks, J. \& Astrup, T. (2010). Life-cycle assessment of selected management options for air pollution control residues from waste incineration. Science of the total environment 408, 4672-4680.

Fruergaard, T., \& Astrup, T. (2010). Optimal utilization of waste to energy in a LCA perspective. Waste Management.

Fruergaard, T., Christensen, T.H. \& Astrup, T. (2009). Energy recovery from waste incineration: Assessing the importance of district heating networks.

Hansen, E., Olsen, S.I., Schmidt, A., Hauschild, M., Hjelmar, O., Bendtsen, N., Poulsen, T.S., 
Hansen, H.H. \& Christensen, K. (2004). Life cycle assessment of landfilled waste (in Danish). Environmental project no. 971, Danish Environmental Protection Agency, Copenhagen, Denmark.

Jensen, J.W., Felby, C., Jørgensen, H., Rønnsch, G.Ø. \& Nørholm, N.D. (2010). Enzymatic processing of municipal solid waste. Waste Management. Available on-line.

Kaparaju, P., Serrano, M., Thomsen, A.B., Kongjan, P. \& Angelidaki, I. (2009). Bioethanol, biohydrogen and biogas production from wheat straw in a biorefinery concept. Bioresource Technology 100, 2562-2568.

Kirkeby, J.T., Birgisdóttir, H., Bhander, G.S., Hauschild, M.Z. \& Christensen T.H. (2007). Modelling of environmental impacts of solid waste landfilling in a life cycle perspective (EASEWASTE). Waste Management 27, 961-970.

Kirkeby, J.T., Hansen, T.L., Birgisdóttir, H., Bhander, G.S., Hauschild, M.Z. \& Christensen, T.H. (2006). Environmental assessment of solid waste systems and technologies: EASEWASTE. Waste Management and Research 24, 3-15.

Larsen, A.W., Merrild, H., Møller, J. \& Christensen, T.H. (2010). Waste collection systems for recyclables: An environmental and economic assessment for the municipality of Aarhus (Denmark). Waste Management 30, 744-754.

Larsen, J., Petersen, M.Ø., Thirup, L., Li, H.W. \& Iversen, F.K. (2008). The IBUS Process Lignocellulosic Bioethanol Close to a Commercial Reality. Chem. Eng. Technol. 31, 765772.

Lohrasby, M., Pourbafrani, M., Niklasson, C. \& Taherzadeh, J. (2010). Process design and economic analysis of a citrus waste biorefinery with biofuels and limonene as products. Bioresource Technology 101, 7382-7388.

Lund, H. (2007). Renewable energy strategies for sustainable development. Energy 32(6), 912-919. 
Manfredi, S. \& Christensen, T.H. (2009). Environmental assessment of solid waste landfilling technologies by means of LCA-modeling (EASEWASTE). Waste Management $29,32-43$.

Mathiesen, B.V., Munster, M. \& Fruergaard, T. (2009). Uncertainties related to the identification of the marginal energy technology in consequential life cycle assessments. Journal of Cleaner Production 17, 1331-1338.

Møller, J., Jansen, J.L. Cour \& Christensen, T.H. (2010). Anaerobic digestion: mass balances and products. Solid Waste Technology and Management.

Møller, J., Fruergaard, T., Riber,C., Astrup, T. \& Christensen, T.H. (2008). Miljøvurdering af affaldsforbrænding og alternativer. DTU Miljø, Institut for Vand og Miljøteknologi, Danmarks Tekniske Universitet, Kgs. Lyngby.

Nielsen, P.H., Oxenbll, K.M., \& Wenzel, H. (2007). Cradle-to-Gate Environmental Assessment of Enzyme Products Produced Industrially in Denmark by Novozymes A/S. Int J LCA 12 (6), 432-438. Updated values (2010).

Novozymes A/S, 2004. Report. America.

Nielsen, M. \& Illerup, J.B. (2006): Danish emission inventories for stationary combustion plants. Inventories until year 2003. Research Notes NERI No. 229. National Environmental Research Institute, Denmark.

Pognani, M., D’Imporzano, G., Scaglia, B. \& Adani, F. (2009). Substituting energy crops with organic fraction of municipal solid waste for biogas production at farm level: a full-scale plant study. Process Biochemistry 44, 817-821.

Riber, C., Petersen, C. \& Christensen, T.H. (2009). Chemical composition of material fractions in Danish household waste. Waste Management 29, 1251-1257.

Rigamonti, L. \& Grosso, M. (2009). Influence of assumptions about selection and recycling efficiencies on the LCA of integrated waste management systems. Int J LCA, 411-419. 
Sander, B., Christensen, B.T., Hansen, E.M., Magid, J. \& Jensen, L.S. (2003). Calibration and validation of the soil organic matter dynamics of the Daisy model with data from the Askov long-term experiments. Soil Biology and Biochemistry 35, 67-76.

Schmidt, A. \& Stromberg, K. (2006). Genanvendelse i LCA - systemudvidelse (Recycling in LCA - system expansion, in Danish), Miljoenyt Nr. 81. Danish Environmental Protection Agency, Copenhagen, Denmark.

Skovgaard, M., Villanueva, A., Andersen, M., \& Helge, L. (2007). Environmental outlooks: municipal waste. ETC/RWM working paper 2007/1.

Stranddorf, H.K., Hoffmann, L. \& Schmidt, A. (2005). Påvirkningskategorier, normalisering og vægtning i LCA - opdatering af udvalgte UMIP97-data. Danish Ministry of the Environment, Miljønyt n. 77.

Talebnia F., Karakashev D., \& Angelidaki I. (2009). Production of bioethanol from wheat straw: an overview on pretreatment, hydrolysis and fermentation. Bioresource Technology 101(13), 4744-4753.

Uihlein, A. \& Schebek, L. (2009). Environmental impacts of a lignocellulose feedstock biorefinery system: An assessment. Biomass and Bioenergy, 33, 793-802.

Weidema, B., Frees, N. \& Nielsen, A.M., (1999). Marginal production technologies for Life Cycle Inventories, International Journal of Life cycle Assessment, 4, 48-56.

Wenzel, H., Hauschild, M.Z. \& Alting L., (1997). Environmental Assessment of Products. Volume 1. 


\section{Captions}

\section{Tables}

Table 1 Waste composition used in this study (\% of each fraction per wet weight)

Table 2 Average chemical composition of the liquid and solid fraction (mg/kg DM) obtained from the waste refinery. The latter was based on modelling and did not include glass and metals which were assumed to be separated for recycling

Table 3 Transfer coefficients to air (\% of input transferred to the air emissions) of selected elements

Table 4 Environmental impact categories and normalization references included in the assessment (Stranddorf et al., 2005; Hansen et al., 2004)

Table 5 Environmental impacts on Non-Toxic and Toxic categories: overall results (mPE/tonne Ww)

Table 6 Energy balance of the five scenarios. The results are reported as GJ of primary energy/tonne ww (rounded values) for both coal- and natural gas-based energy systems. Energy consumption is expressed as positive value while avoided energy consumption as negative

Table 7 Sensitivity analysis: results are given as net difference ( $\Delta \mathrm{mPE} /$ tonne ww) with respect to the value of the original scenario $(\triangle \mathrm{mPE}=\mathrm{mPE}$ new scenario-mPE original scenario $)$. Negative values mean higher savings. Only the energy system LT-Coal (coal as marginal energy) was considered for the analysis 


\section{Figures}

Figure 1 The waste refinery process (mass and energy flows)

Figure 2 Overview of the system boundary of the LCA study

Figure 3 Impact potentials (mPE/tonne ww) associated with the treatment of one tonne ww in the waste refinery and (eventual) subsequent drying process (only relevant environmental categories)

Figure 4 Environmental impacts on relevant Non-Toxic and Toxic impact categories: process contributions 


\section{Tables}

Table 1 Waste composition used in this study (\% of each fraction per wet weight)

\begin{tabular}{lll}
\hline \multirow{2}{*}{ Fraction } & $\begin{array}{l}\text { Average Danish residual waste } \\
\text { Riber et al. (2009) }\end{array}$ & $\begin{array}{l}\text { Average European MSW } \\
\text { Christensen et al. (2009) }\end{array}$ \\
\hline Organic & 45.1 & 35 \\
Paper & 12.1 & 22 \\
Plastic & 9.2 & 10 \\
Glass & 2.9 & 6 \\
Metal & 3.5 & 4 \\
Textile & 1.9 & 3 \\
Other & 25.3 & 20 \\
\hline Sum & 100 & 100 \\
\hline
\end{tabular}


Table 2 Average chemical composition of the liquid and solid fraction ( $\mathrm{mg} / \mathrm{kg} \mathrm{DM})$ obtained from the waste refinery. The latter was based on modelling and did not include glass and metals which were assumed to be separated for recycling

\begin{tabular}{l|l|l|l|l|l}
\hline Element & Liquid & Solid $^{1}$ & Element & Liquid & Solid $^{1}$ \\
\hline $\mathrm{C}$ & 411 & 503 & $\mathrm{P}$ & 2.2 & 2.5 \\
$\mathrm{H}$ & 55.8 & 68.6 & $\mathrm{As}$ & 0 & 0.01 \\
$\mathrm{~N}$ & 16.9 & 10.1 & $\mathrm{Ba}$ & 0.09 & 0 \\
$\mathrm{~S}$ & 2 & 0.3 & $\mathrm{Cd}$ & 0 & 0.004 \\
$\mathrm{Cl}$ & 12 & 16.9 & $\mathrm{Cr}$ & 0.02 & 0.2 \\
$\mathrm{Al}$ & 6.9 & 2.4 & $\mathrm{Cu}$ & 0.02 & 1.1 \\
$\mathrm{Ca}$ & 25.6 & 16.3 & $\mathrm{Hg}$ & $2 \mathrm{E}-4$ & 0.001 \\
$\mathrm{Fe}$ & 2.9 & 12.1 & $\mathrm{Mn}$ & 0.05 & 0.04 \\
$\mathrm{~K}$ & 7.4 & 4.0 & $\mathrm{Ni}$ & 0.01 & 0.04 \\
$\mathrm{Mg}$ & 2 & 1.3 & $\mathrm{~Pb}$ & 0.02 & 0.3 \\
$\mathrm{Na}$ & 16 & 6.6 & $\mathrm{Zn}$ & 0.14 & 1.3 \\
\hline
\end{tabular}

${ }^{1}$ After separation of recyclables (metals and glass)

Table 3 Transfer coefficients to air (\% of input transferred to the air emissions) of selected elements

\begin{tabular}{l|l|l}
\hline Element & $\begin{array}{l}\text { Transfer coefficient } \\
\text { incineration }(\% \mathrm{TS})\end{array}$ & $\begin{array}{l}\text { Transfer coefficient co- } \\
\text { combustion }(\% \mathrm{TS})\end{array}$ \\
\hline $\mathrm{Al}$ & - & 0.1 \\
$\mathrm{As}$ & 0.204 & 0.39 \\
$\mathrm{Cd}$ & 0.006 & 0.99 \\
$\mathrm{Cr}$ & 0.068 & 0.17 \\
$\mathrm{Cu}$ & 0.009 & 0.17 \\
$\mathrm{Fe}$ & - & - \\
$\mathrm{Hg}$ & 3.5 & 28.5 \\
$\mathrm{Mg}$ & - & - \\
$\mathrm{Mn}$ & 0.004 & 0.08 \\
$\mathrm{Ni}$ & 0.125 & 0.29 \\
$\mathrm{~Pb}$ & 0.015 & 0.35 \\
$\mathrm{Zn}$ & - & - \\
\hline
\end{tabular}


Table 4 Environmental impact categories and normalization references included in the assessment (Stranddorf et al., 2005; Hansen et al., 2004)

\begin{tabular}{l|cccc} 
Non-Toxicity categories & Acronym & $\begin{array}{c}\text { Physical } \\
\text { basis }\end{array}$ & $\begin{array}{c}\text { Normalization reference } \\
\text { EU-15 }\end{array}$ & Unit \\
\hline Global Warming & GW & Global & 8,700 & $\mathrm{~kg} \mathrm{CO}_{2}$-eq. $/ \mathrm{person} / \mathrm{yr}$ \\
\hline Acidification & AC & Regional & 74 & $\mathrm{~kg} \mathrm{SO}_{2}$-eq. $/ \mathrm{person} / \mathrm{yr}$ \\
\hline Nutrient Enrichment & NE & Regional & 119 & $\mathrm{~kg} \mathrm{NO}_{3}{ }^{-}$-eq. $/ \mathrm{person} / \mathrm{yr}$ \\
\hline Toxicity categories & Acronym & $\begin{array}{c}\text { Physical } \\
\text { basis }\end{array}$ & Normalization reference & EU-15 \\
\hline $\begin{array}{l}\text { Ecotoxicity in water } \\
\text { chronic }\end{array}$ & ETwc & Regional & 352,000 & $\mathrm{~m}^{3}$ water $/ \mathrm{person} / \mathrm{yr}$ \\
\hline Human toxicity via soil & HTs & Regional & 127 & $\mathrm{~m}^{3}$ soil /person/yr \\
\hline Human toxicity via water & HTw & Regional & 50,000 & $\mathrm{~m}^{3}$ water $/ \mathrm{person} / \mathrm{yr}$ \\
\hline
\end{tabular}


Table 5 Environmental impacts on Non-Toxic and Toxic categories: overall results (mPE/tonne ww)

\begin{tabular}{|c|c|c|c|c|c|c|}
\hline \multirow{2}{*}{ Category } & \multirow{2}{*}{ Scenario } & \multicolumn{5}{|c|}{ Energy scenario } \\
\hline & & ST-CPH & LT-CO & LT-NG & LT-CONH & LT-NGNH \\
\hline \multirow{5}{*}{ GW } & INC & -13 & -67 & -16 & -29 & -7 \\
\hline & $\mathrm{CC}-\mathrm{CC}$ & -81 & -106 & -44 & -80 & -38 \\
\hline & CC-INC & -40 & -81 & -28 & -68 & -20 \\
\hline & BG-CC & -36 & -64 & -16 & -52 & -16 \\
\hline & BG-INC & 4 & -40 & 1 & -16 & 1 \\
\hline \multirow{5}{*}{$\mathrm{AC}$} & INC & -5 & -13 & 1 & -3 & 2 \\
\hline & $\mathrm{CC}-\mathrm{CC}$ & -12 & -22 & -7 & -16 & -6 \\
\hline & CC-INC & -9 & -19 & -5 & -15 & -4 \\
\hline & BG-CC & -8 & -16 & -5 & -13 & -5 \\
\hline & BG-INC & -5 & -13 & -3 & -8 & -3 \\
\hline \multirow{5}{*}{$\mathrm{NE}$} & INC & 7 & -3 & 8 & 7 & 10 \\
\hline & $\mathrm{CC}-\mathrm{CC}$ & 9 & 1 & 10 & 7 & 11 \\
\hline & CC-INC & 14 & 5 & 14 & 8 & 15 \\
\hline & BG-CC & 49 & 43 & 50 & 46 & 50 \\
\hline & BG-INC & 53 & 47 & 54 & 52 & 54 \\
\hline \multirow{5}{*}{ ETwc } & INC & -235 & -157 & -143 & -152 & -143 \\
\hline & $\mathrm{CC}-\mathrm{CC}$ & -189 & -210 & -187 & -207 & -187 \\
\hline & CC-INC & -255 & -227 & -208 & -225 & -208 \\
\hline & BG-CC & -184 & -199 & -183 & -197 & -183 \\
\hline & BG-INC & -251 & -217 & -206 & -214 & -206 \\
\hline \multirow{5}{*}{ HTw } & INC & 107 & 96 & 108 & 101 & 109 \\
\hline & CC-CC & 175 & 174 & 192 & 177 & 192 \\
\hline & CC-INC & 19 & 13 & 28 & 15 & 28 \\
\hline & BG-CC & 193 & 187 & 200 & 189 & 200 \\
\hline & BG-INC & 37 & 26 & 35 & 29 & 35 \\
\hline \multirow{5}{*}{ HTs } & INC & -29 & -26 & -22 & -24 & -21 \\
\hline & $\mathrm{CC}-\mathrm{CC}$ & -17 & -18 & -11 & -17 & -11 \\
\hline & CC-INC & -74 & -73 & -68 & -72 & -68 \\
\hline & BG-CC & 212 & 210 & 214 & 210 & 214 \\
\hline & BG-INC & 155 & 155 & 158 & 155 & 158 \\
\hline
\end{tabular}


Table 6 Energy balance of the five scenarios. The results are reported as GJ of primary energy/tonne ww (rounded values) for both coal- and natural gas-based energy systems.

Energy consumption is expressed as positive value while avoided energy consumption as negative

\begin{tabular}{|c|c|c|c|c|c|c|c|c|c|c|}
\hline \multirow{2}{*}{ Process } & \multicolumn{2}{|c|}{ INC } & \multicolumn{2}{|c|}{ CC-CC } & \multicolumn{2}{|c|}{ CC-INC } & \multicolumn{2}{|c|}{ BG-CC } & \multicolumn{2}{|c|}{ BG-INC } \\
\hline & Coal & $\mathrm{NG}$ & Coal & NG & Coal & NG & Coal & NG & Coal & NG \\
\hline Transportation & 0.3 & 0.3 & 0.3 & 0.3 & 0.3 & 0.3 & 0.2 & 0.2 & 0.2 & 0.2 \\
\hline Waste refinery & - & - & 3.8 & 3.4 & 3.8 & 3.4 & 3.8 & 3.4 & 3.8 & 3.4 \\
\hline Drying process & - & - & 1.9 & 0.3 & 1.9 & 0.3 & - & - & - & - \\
\hline INC - El substitution & -7.7 & -7 & - & - & -4.0 & -3.6 & - & - & -4.0 & -3.6 \\
\hline INC - Heat substitution & -4.2 & -0.8 & - & - & -2.2 & -0.5 & - & - & -2.2 & -0.5 \\
\hline CHP - El substitution & - & - & -17.7 & -16 & -9.3 & -8.4 & -11.7 & -9.1 & -5.3 & -1.5 \\
\hline CHP - Heat substitution & - & - & -3.1 & -0.8 & -1.6 & -0.4 & -2.0 & -0.6 & -0.5 & -0.3 \\
\hline Ash treatment & 0.04 & 0.03 & 0.02 & 0.02 & 0.02 & 0.01 & 0.01 & 0.01 & 0.01 & 0.01 \\
\hline Al Recycling & -0.3 & -0.3 & -0.7 & -0.7 & -0.7 & -0.7 & -0.7 & -0.7 & -0.7 & -0.7 \\
\hline Glass Recycling & - & - & -0.1 & -0.1 & -0.1 & -0.1 & -0.1 & -0.1 & -0.1 & -0.1 \\
\hline Fe Recycling & -0.2 & -0.2 & -0.3 & -0.3 & -0.4 & -0.4 & -0.3 & -0.3 & -0.4 & -0.4 \\
\hline $\begin{array}{l}\text { Substitution of inorganic } \\
\text { fertilizers }\end{array}$ & - & - & - & - & - & - & -0.2 & -0.2 & -0.2 & -0.2 \\
\hline Total & -12.1 & -8.0 & -15.9 & -13.9 & -12.3 & -10.1 & -11.6 & -7.5 & -9.4 & -3.7 \\
\hline
\end{tabular}


Table 7 Sensitivity analysis: results are given as net difference $(\Delta \mathrm{mPE} /$ tonne ww $)$ with respect to the value of the original scenario $(\triangle \mathrm{mPE}=\mathrm{mPE}$ new scenario-mPE original scenario). Negative values mean higher savings. Only the energy system LT-Coal (coal as marginal energy) was considered for the analysis

\begin{tabular}{l|l|lllllll}
\hline \multirow{2}{*}{ Category } & Scenario & \multicolumn{7}{c}{ Parameter assessed } \\
& & EU MSW & ENZ $(\downarrow)$ & PL REC. & $\mathrm{CH}_{4}(\downarrow)$ & $\mathrm{CH}_{4}(\uparrow)$ & $\mathrm{RR}(\downarrow)$ & $\eta_{\text {el }}(\uparrow)$ \\
\hline \multirow{5}{*}{ GW } & INC & -8 & 0 & 0 & 0 & 0 & 0 & 0 \\
& CC-CC & 4 & -8 & 3 & 0 & 0 & 12 & 0 \\
& CC-INC & 4 & -8 & 0 & 0 & 0 & 6 & 0 \\
& BG-CC & -3 & -8 & -2 & 7 & -7 & 12 & -11 \\
& BG-INC & -2 & -8 & 0 & 7 & -7 & 6 & -11 \\
\hline \multirow{5}{*}{ AC } & INC & -3 & 0 & 0 & 0 & 0 & 0 & 0 \\
& CC-CC & 0 & 0 & -2 & 0 & 0 & 9 & 0 \\
& CC-INC & 4 & 0 & -2 & 0 & 0 & 8 & 0 \\
& BG-CC & -3 & 0 & -5 & 4 & -4 & 7 & -2 \\
& BG-INC & -2 & 0 & -2 & 4 & -4 & 2 & -2 \\
\hline \multirow{5}{*}{ ETwc } & INC & -25 & 0 & 0 & 0 & 0 & 0 & 0 \\
& CC-CC & -36 & 0 & 3 & 0 & 0 & 61 & 0 \\
& CC-INC & -37 & 0 & 2 & 0 & 0 & 21 & 0 \\
& BG-CC & -34 & 0 & 2 & 33 & -33 & 65 & -2 \\
& BG-INC & -34 & 0 & 2 & 33 & -33 & 19 & -2 \\
\hline \multirow{5}{*}{ HTw } & INC & 18 & 0 & 0 & 0 & 0 & 0 & 0 \\
& CC-CC & 33 & 0 & 1 & 0 & 0 & 270 & 0 \\
& CC-INC & 7 & 0 & 1 & 0 & 0 & 36 & 0 \\
& BG-CC & 38 & 0 & 2 & 0 & 0 & 268 & -2 \\
& BG-INC & 11 & 0 & 1 & 0 & 0 & 33 & -2 \\
\hline \multirow{5}{*}{ HTs } & INC & 0 & 0 & 0 & 0 & 0 & 0 & 0 \\
& CC-CC & -2 & 0 & 0 & 0 & 0 & 100 & 0 \\
& CC-INC & -9 & 0 & 1 & 0 & 0 & 18 & 0 \\
& BG-CC & -18 & 0 & -1 & 0 & 0 & 98 & -3 \\
& BG-INC & -25 & 0 & 1 & 0 & 0 & 15 & -3 \\
\hline
\end{tabular}

EU MSW = Average EU Municipal Solid Waste composition

ENZ $(\downarrow)=$ Decreased GW impact from enzyme production $\left(2 \mathrm{kgCO}_{2}\right.$-eq $\left./ \mathrm{kg} \mathrm{enz}\right)$

PL REC. $=$ Plastic recycling $(21 \%)$

$\mathrm{CH}_{4}(\downarrow)=$ Decreased methane potential (60\% VS degradation)

$\mathrm{CH}_{4}(\uparrow)=$ Increased methane potential $(90 \%$ VS degradation)

$\mathrm{RR}(\downarrow)=$ Decreased recycling rate $(50 \%)$

$\eta_{\mathrm{el}}(\uparrow)=$ Higher electricity recovery in Integrated Gas Combined Cycle $(60 \%)$ 


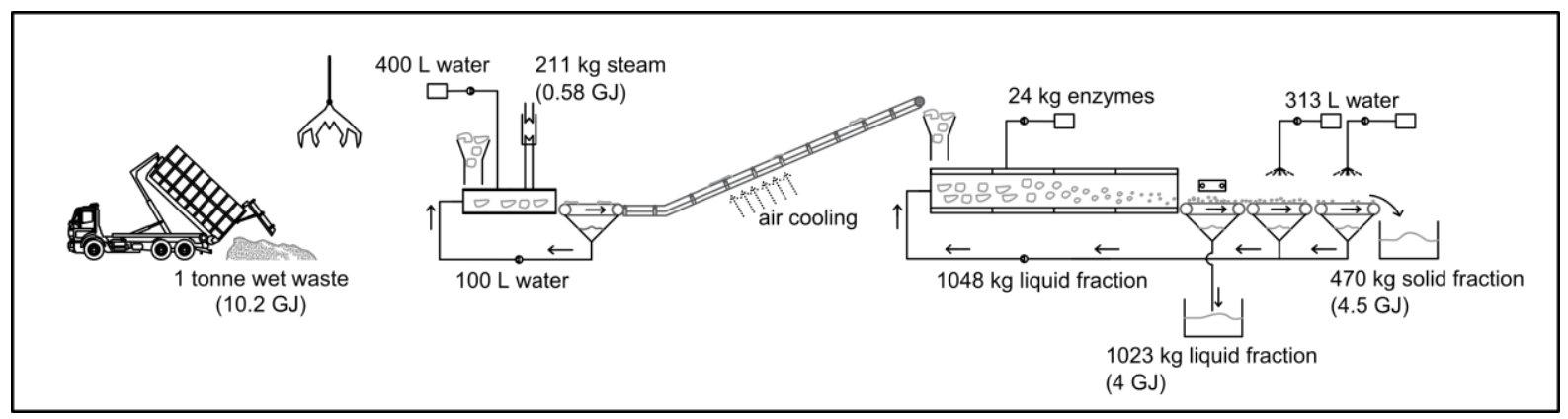




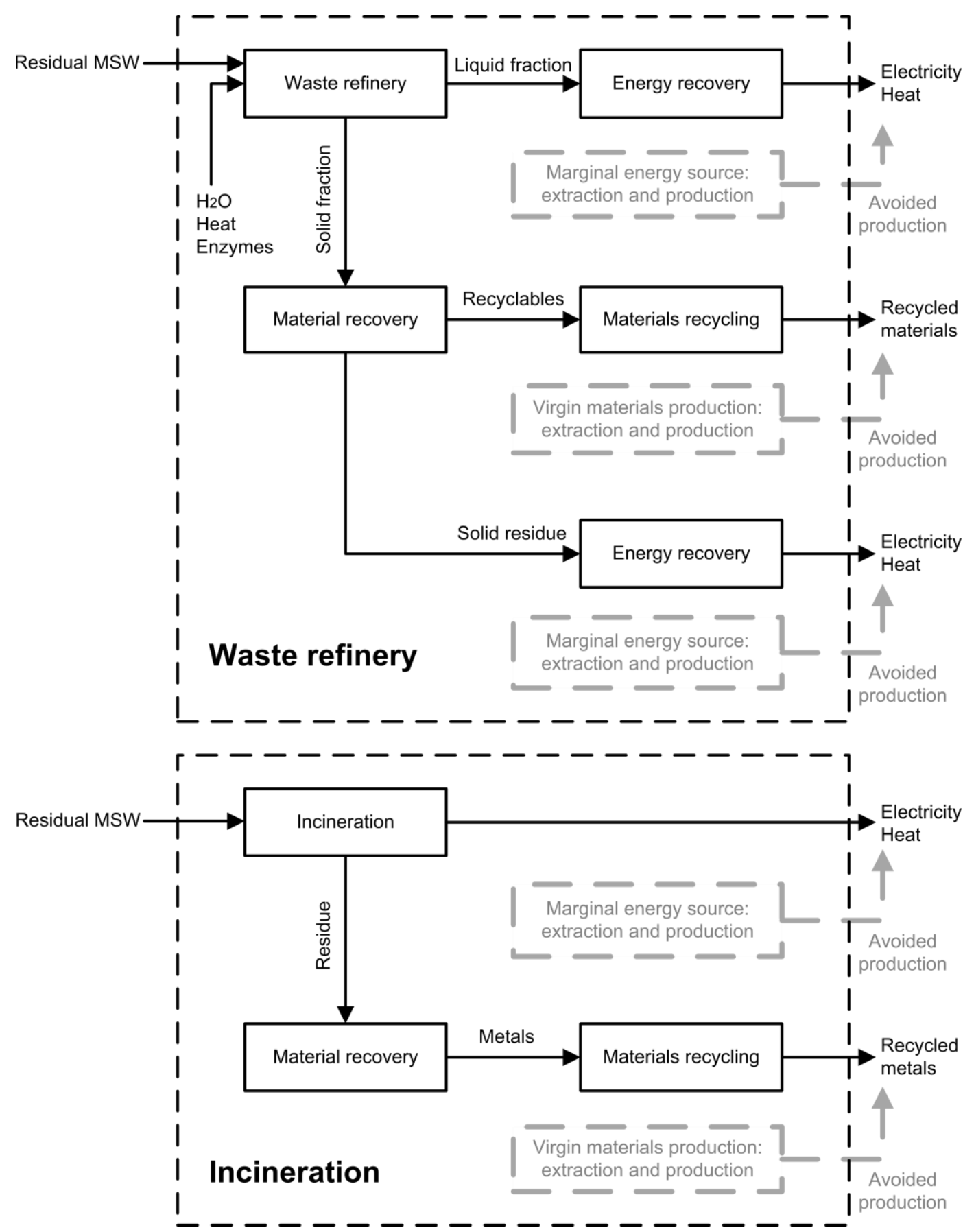




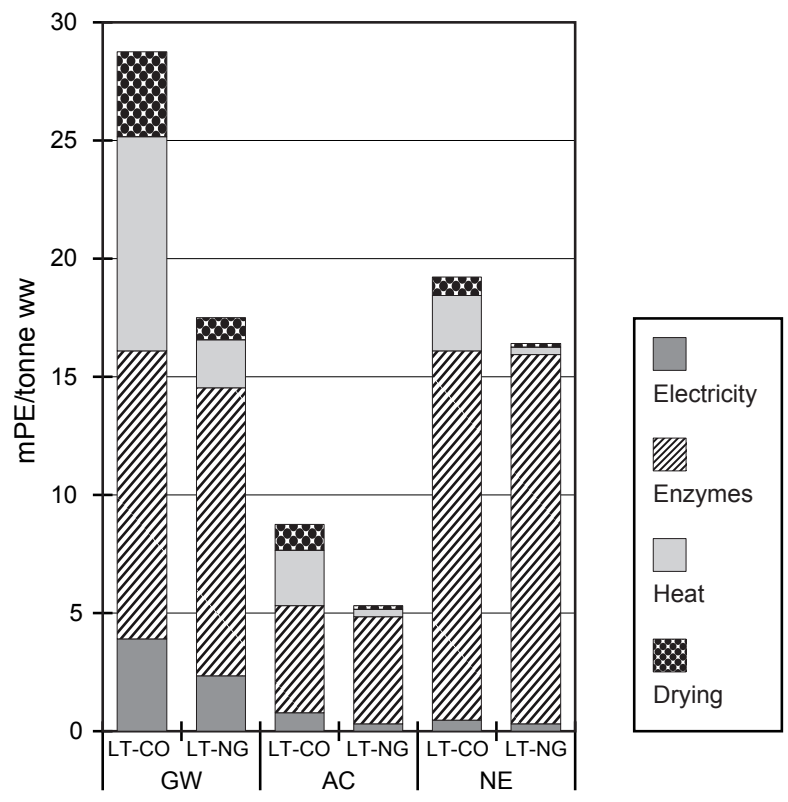



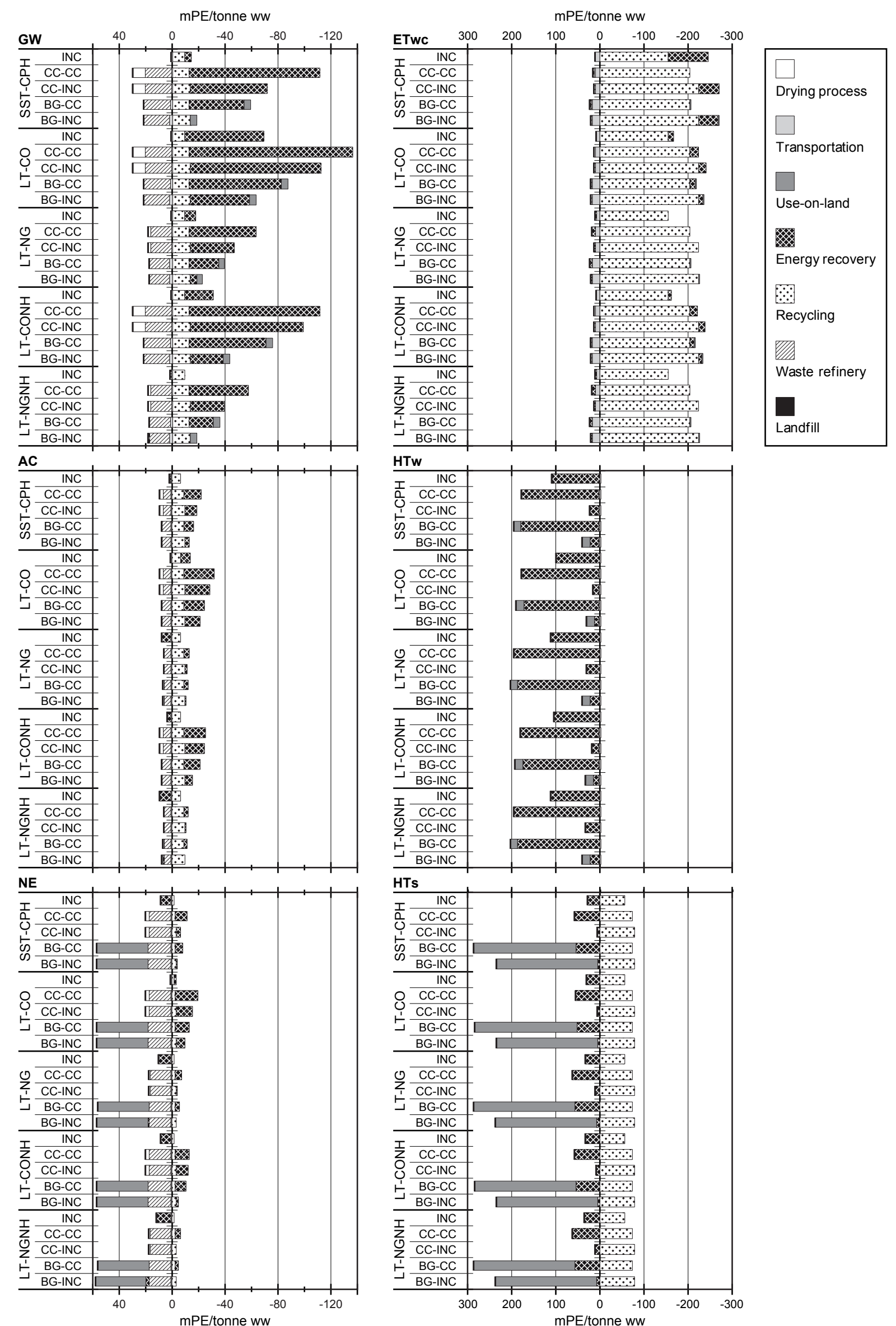